\title{
PROBLEMS AND METHODS OF DATING LOW-ACTIVITY SAMPLES BY LIQUID SCINTILLATION COUNTING
}

\author{
KH. A. ARSLANOV, T. V. TERTYCHNAYA and S. B. CHERNOV \\ Geographical Research Institute, St. Petersburg State University, Sredniy Prospect 41 \\ St. Petersburg 199004 Russia
}

\begin{abstract}
The important problem of contamination of old samples by younger ${ }^{14} \mathrm{C}$ necessitates treatment of organic and carbonate samples to ensure more complete removal of contaminating carbon. Here we present studies of chemical procedures for the liquid scintillation method of ${ }^{14} \mathrm{C}$ dating undertaken since 1960 in the former USSR. We discuss new procedures such as lithium carbide synthesis from charred organic samples and benzene synthesis on a $\mathrm{V}_{2} \mathrm{O}_{5} \cdot \mathrm{Al}_{2} \mathrm{O}_{3} \cdot \mathrm{SiO}_{2}$ catalyst, as well as memory effect in the carbide synthesis procedure and characteristics of two homemade counters.
\end{abstract}

\section{INTRODUCTION}

The main methodological problem in reconstructing Late Pleistocene and Paleolithic chronology is the difficulty of obtaining reliable dates from old samples. Even the smallest impurity $(<0.1-$ $0.2 \%$ ) of carbon younger than the sample strongly affects the sample age. Sample contamination results from percolation of humic and fulvic acids and their complexes, root penetration and bacterial, fungal and algal activity.

To prevent contamination of organic sediments, one must collect samples from zones that are isolated from atmospheric $\mathrm{CO}_{2}$, roots and autotrophic microorganisms (Arslanov, Butomo and Kind 1964). We separate peat and plant detritus samples on a sieve and date coarse $(\geq 0.25-1 \mathrm{~mm})$ and fine $(\leq 0.25-1 \mathrm{~mm})$ fractions. In some cases, we are able to identify contamination of the coarse fraction because of its younger age (Arslanov 1971); dating different fractions also helps us to recognize contamination by redeposited carbon, which makes the ${ }^{14} \mathrm{C}$ age older. Contamination by finely dispersed plant residues undoubtedly affects dates on fine and coarse fractions; on the other hand, agreement between these dates confirms their reliability.

Dating of in-situ fossil plant material selected from the total mass of plant detritus enables us to estimate the age of organic sediments. Thus, we dated arctic-boreal plant remains (e.g., Betula nana) from Late Pleistocene plant detritus in the Drichaluki section, Belorussia.

\section{METHODS AND RESULTS}

\section{Sample Pretreatment}

We extracted humic acid from wood, peat, plant detritus and charcoal by hot treatment in $3 \% \mathrm{HCl}$, $2 \% \mathrm{NaOH}$ and again 3\% $\mathrm{HCl}$. We studied the relation between extracted humic acid and the duration of wood and peat pretreatment (Arslanov et al. 1968), and found that most of the humic acids are extracted by hot treatment in $2 \% \mathrm{NaOH}$ over $30-90 \mathrm{~min}$; a small quantity is removed completely only after a 5-h treatment 2-3 times. As a result, we use the following routine procedure: 1) for young samples, a single 2 -h treatment in hot $2 \% \mathrm{NaOH} ; 2$ ) for old samples (20-55 ka BP), a double 5-h treatment; 3) for samples expected to be $>55 \mathrm{ka} \mathrm{BP}$, three 5 -h treatments (Arslanov et al. 1968). Using this method we have obtained many dates for wood and peat of $>55-62 \mathrm{ka}$.

Some samples, such as decomposed wood, peat moss and finely dispersed charcoal from archaeological sites can dissolve completely in hot alkali. These samples must be treated in $2 \%$ 
$\mathrm{NaOH}$ at room temperature (after hot acid treatment and $\mathrm{Ca}^{2+}$ removal). In so doing, most humic acid contamination should be removed. After washing, a sample is treated in hot $\left(85-90^{\circ} \mathrm{C}\right) 1 \%$ $\mathrm{NaOH}$ for 30-120 min, the duration of which depends on the sample's solubility. To estimate contamination, we date insoluble and soluble (humic acid) fractions after hot extraction (Arslanov and Tertychnaya 1983).

Samples with low carbon content, such as humus sediments, organic silt and paleosol, must be dated by dissolving the fraction in hot $2 \% \mathrm{NaOH}$ after alkali treatment at room temperature (Arslanov 1975). It is also desirable to date the humic-acid fraction extracted by $2 \% \mathrm{NaOH}$ at room temperature, which contains the bulk of humic-acid contaminants. On the other hand, contamination of the smallest root tissue strongly affects the age of the fraction extracted by hot alkali (Arslanov and Kozyreva 1976; Arslanov and Tertychnaya 1983). Our procedure for fossil bone treatment is detailed elsewhere in this issue (Arslanov and Svezhentsev 1993).

Both external and internal fractions are used to ${ }^{14} \mathrm{C}$-date old shells. The surface layer of shell $(30 \%$ by sample weight) is removed by dissolution in $\mathrm{HCl}$ (Arslanov et al. 1978b, 1981). For young shells (to $\sim 14 \mathrm{ka} \mathrm{BP}$ ), we observed good agreement between these two fractions. For old shells, the outer fraction is almost always younger than the inner fraction. Parallel ${ }^{14} \mathrm{C}$ and ${ }^{230} \mathrm{Th} /{ }^{234} \mathrm{U}$ dating shows that even the inner fraction has a distinctly younger ${ }^{14} \mathrm{C}$ age (Arslanov et al. 1978a). For example, the age of the inner fraction of Cyprina islandica is $38,940 \pm 450 \mathrm{BP}$ (by ${ }^{14} \mathrm{C}$ ) and $114,000 \pm 4000$ BP (by ${ }^{230} \mathrm{Th} /{ }^{34} \mathrm{U}$ ). The sediments containing these shells were dated by micropaleontological methods to the Eem transgression; this suggests that young carbonates penetrated even into the internal layer of old shells. Thus, ${ }^{14} \mathrm{C}$ dates on old shells must be considered minimum ages.

\section{Benzene Synthesis}

Our laboratory has employed liquid scintillation counting for ${ }^{14} \mathrm{C}$ measurements since 1960. Initially, we used an ethylbenzene cocktail; $~ 100$ samples were dated using this cocktail from 1960 to 1963 (Starik, Arslanov and Zharkov 1960; Starik et al. 1961). At the same time, benzene was synthesized from acetylene by Reppe's method; synthesis occurred in a stainless-steel reactor at high pressure. Benzene yield was 50\% (Starik, Arslanov and Zharkov 1960; Starik et al. 1961). Many samples from Quaternary and ocean sediments were dated using this technique (Starik and Arslanov 1961). These were probably the first results worldwide obtained using benzene for old sediments.

In 1963, we implemented Ziegler's catalyst system that consisted of (iso- $\left.\mathrm{C}_{4} \mathrm{H}_{9}\right)_{3} \mathrm{Al}$ and $\mathrm{TiCl}_{4}$ (Starik, Arslanov and Klener 1963; Arslanov 1967). Benzene synthesis occurred in a xylene medium at $-6^{\circ} \mathrm{C}$ to $-10^{\circ} \mathrm{C}$. Acetylene was trimerized at $\sim 30-40$ liter per hour to achieve $80 \%$ benzene yield. We obtained $>100 \mathrm{ml}$ of benzene in order to date, without isotopic enrichment, samples $\geq 62 \mathrm{ka}$ BP (Arslanov et al. 1968). This procedure was used in many Soviet laboratories from 1963 to 1967. In 1967, we developed two new catalysts for benzene synthesis from acetylene: $\mathrm{NiMoO}_{4}$ coated on active $\mathrm{Al}_{2} \mathrm{O}_{3}$, and $\mathrm{V}_{2} \mathrm{O}_{5}$ coated on $\mathrm{Al}_{2} \mathrm{O}_{3} \cdot \mathrm{SiO}_{2}$. We also studied the synthesis procedure for $\mathrm{CrO}_{3}$ coated on $\mathrm{Al}_{2} \mathrm{O}_{3} \cdot \mathrm{SiO}_{2}$ (Arslanov and Gromova 1968, 1969). These catalysts allowed synthesis of high-purity benzene at room temperature with $95-98 \%$ yield and production of 60-70 $\mathrm{g}$ benzene per $100 \mathrm{~g}$ of catalyst. Since 1967, almost all laboratories in the former USSR have used the $\mathrm{V}_{2} \mathrm{O}_{5} \cdot \mathrm{Al}_{2} \mathrm{O}_{3} \cdot \mathrm{SiO}_{2}$ catalyst for routine benzene syntheses. 


\section{Preparation of Acetylene}

From 1960 to 1963 , we obtained acetylene from $\mathrm{SrCO}_{3}(100-300 \mathrm{~g})$ by the modified Suess technique (Starik et al. 1961). In 1963, we developed a new procedure of $\mathrm{Li}_{2} \mathrm{C}_{2}$ synthesis from charcoal from charred samples, wherein the charcoal reacted with $\mathrm{Li}$ at $800^{\circ} \mathrm{C}$ (Starik, Arslanov and Klener 1963); this technique required less time than for synthesis from $\mathrm{CO}_{2}$ and acetylene yield was higher (as much as 25-30 liter per synthesis). These advantages were also noted by Noakes et al. (1965) and Tamers $(1969,1975)$. Acetylene synthesis from samples with low carbonate content is performed by a modified Barker procedure (Polach and Stipp 1967). To prevent $\mathrm{Li}$ sublimation, $\mathrm{CO}_{2}$ absorption occurs at lower temperature $\left(500-600^{\circ} \mathrm{C}\right)$. The temperature is then increased to $800^{\circ} \mathrm{C}$ and is sustained for $30 \mathrm{~min}$ (Arslanov and Tertychny 1970). Under these conditions, $\mathrm{C}_{2} \mathrm{H}_{2}$ yield is $\sim 95 \%$ with $10 \% \mathrm{Li}$ excess. The modified Tamers (1969) method is used for samples with high carbonate content. The reaction is exothermic and occurs at a high rate, so that the stainless-steel cylindrical vessel with sample and $\mathrm{Li}$ may be soldered to the base of the reactor. To prevent this effect, the prepared $\mathrm{CaCO}_{3}$ is placed on the bottom of the reactor under the stainless-steel cylindrical vessel with $\mathrm{Li}$. Then the evacuated reactor is heated to $800^{\circ} \mathrm{C}$ and is sustained at this temperature for $1 \mathrm{~h}$.

We observed a memory effect in producing $\mathrm{Li}_{2} \mathrm{C}_{2}$ (Arslanov and Filonov 1978). For example, benzene synthesized from anthracite (after synthesis of $\mathrm{Li}_{2} \mathrm{C}_{2}$ from recent carbon in the same reactor) had a ${ }^{14} \mathrm{C}$ activity of $0.8 \%$ of the modern ${ }^{14} \mathrm{C}$ standard, with an apparent age of 38,680 \pm $390 \mathrm{BP}$. Such contamination was also observed in $\mathrm{Li}_{2} \mathrm{C}_{2}$ synthesis from $\mathrm{CO}_{2}$ and $\mathrm{CaCO}_{3}$. Radnell and Muller (1980) investigated a similar effect; Arslanov (1987) discussed possible causes of this effect. We took two steps to reduce this memory effect: 1 ) we used a titanium cylindrical vessel instead of stainless steel or iron for $\mathrm{Li}_{2} \mathrm{C}_{2}$ synthesis from charcoal; 2) we treated the iron vessel for 8-10 h in ambient conditions with a solution of $\mathrm{K}_{2} \mathrm{Cr}_{2} \mathrm{O}_{7}+\mathrm{H}_{2} \mathrm{SO}_{4}$ after $\mathrm{Li}_{2} \mathrm{C}_{2}$ synthesis from $\mathrm{CO}_{2}$ and $\mathrm{CaCO}_{3}$. We also observed a memory effect in the benzene synthesis line $(0.5 \%$ of modern standard). We solved this problem by installing a benzene line made completely of glass, Teflon and stainless steel. The acetylene was purified with a solution of $\mathrm{CuCl}_{2}+\mathrm{FeCl}_{3}+\mathrm{H}_{2} \mathrm{SO}_{4}$, and dried with $\mathrm{KOH}$ pellets.

\section{Measurement of the Activity}

Coincidence scintillation settings worked out by Chernov, Arslanov and Ryvkin (1978) are used for sample dating. We use 2,5-diphenyloxazole (PPO) and POPOP scintillators added to benzene in concentrations of $4 \mathrm{~g} \mathrm{liter}^{-1}$ and $0.1 \mathrm{~g} \mathrm{liter}^{-1}$, respectively. The solution is poured into a thinwalled quartz spherical vial, located between two photomultipliers at the focus of two parabolic reflectors. Shielding consists of layers of $10 \mathrm{~cm}$ lead (outer layer), $10 \mathrm{~cm}$ paraffin with boratic acid (10\%) and $5 \mathrm{~cm}$ lead (inner layer). A second setting shield chamber is made of steel with upper and side thicknesses of $30 \mathrm{~cm}$ and $20 \mathrm{~cm}$, respectively; it also contains a mercury shield and a cosmic neutron shield of paraffin with boratic acid. The scintillation detector is set within a doublewalled stainless-steel cylindrical container. Between the inner and outer wall of the cylinder is 2.5 $\mathrm{cm}$ of mercury for added cosmic-ray shielding. Good stability of the coincidence setting is obtained with values of the photomultiplier tubes' operating bias on the plateau of their counting characteristics (Fig. 1). Counting efficiency and plateau width depend on the window width of the amplitude discriminator. Table 1 shows the counting parameters that we employ.

We make a quenching correction for benzene samples with reduced scintillation efficiency. Bromobenzene is used as a scintillator quencher, added stepwise in small volumes (in $0.002-0.01 \mathrm{ml}$ ) in ${ }^{14} \mathrm{C}$ standard and background benzene samples. Scintillation efficiency was finally measured by 
TABLE 1. Laboratory Counting Parameters

\begin{tabular}{cccccc}
\hline $\begin{array}{c}\text { Setting } \\
\text { no. }\end{array}$ & $\begin{array}{c}\text { Vial volume } \\
(\mathrm{ml})\end{array}$ & $\begin{array}{c}\text { Modern standard } \\
\text { cpm }\end{array}$ & $\begin{array}{c}\text { Background } \\
\text { cpm }\end{array}$ & $\begin{array}{c}\text { Factor of } \\
\text { merit }\end{array}$ & $\begin{array}{c}\text { Maximum } \\
\text { age (BP) } \\
(2 \text { o, 48 h) }\end{array}$ \\
\hline 1 & 22.09 & 141.5 & 3.38 & 77.0 & 58,500 \\
1 & 12.00 & 72.6 & 2.2 & 48.7 & 54,850 \\
2 & 8.46 & 56.8 & 1.9 & 41.0 & 53,500 \\
\hline
\end{tabular}

measuring the maximum energy of Compton electrons of ${ }^{137} \mathrm{Cs} .{ }^{14} \mathrm{C}$ laboratories in the former USSR use the five-fold standard prepared in the Geological Institute of the Academy of Science (GIN) by adding a calibrated amount of ${ }^{14} \mathrm{C}$-tracer benzene to the dead benzene. The activity of this laboratory standard is about five times greater than the activity of 1846-1855 wood. The GIN standard was prepared in 1971 and 1981. Precise measurements of the ratio of the standard's 1971 activity to $1846-1855$ wood were performed in our laboratory, with the result of $4.946 \pm 0.008$ (Chernov and Arslanov 1978). $\delta^{14} \mathrm{C}$ was determined in 51 samples of $1744-1884$ tree rings by using this standard value; these data agree well with the average value (within the $0.2 \%$ error range) of the same data obtained by foreign laboratories that use the NBS standard (Arslanov et al. 1978b). The ratio of 1981 GIN-standard activity to $95 \%$ activity of NBS standard (SRM-4990), including the $\delta^{13} \mathrm{C}$ correction of benzene obtained from oxalic acid, is 5.0128 \pm 0.0107 (Arslanov, Chernov and Tertychnaya 1987). The ratio of GIN to the absolute activity of NBS standard corrected to 1950 is $4.992 \pm 0.011$.

\section{5. fold standard counting rate, cpm}

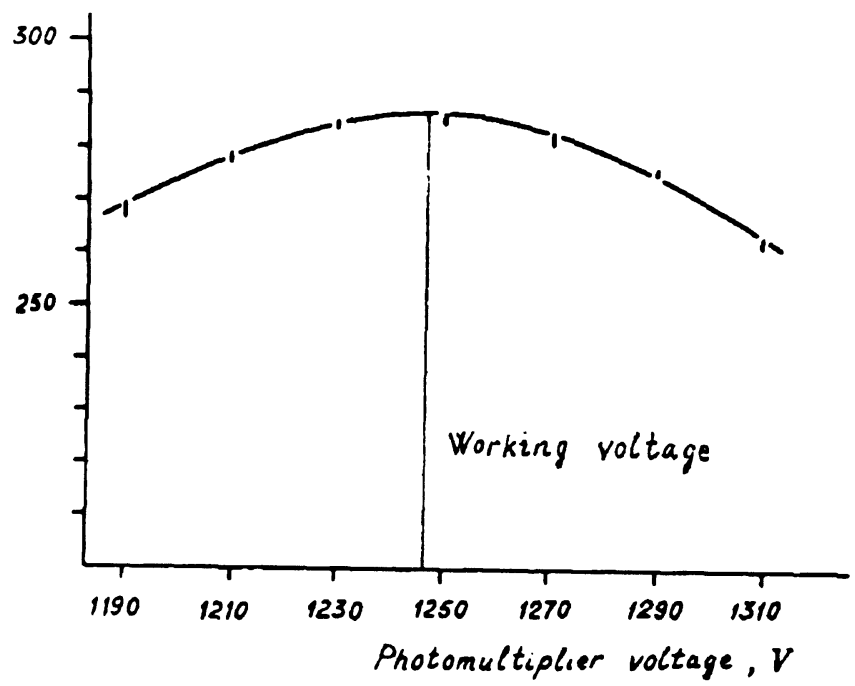

Fig 1. Counting characteristics of coincidence scintillation settings. The inclination of the plateau $0.5 \%$ corresponds to the changes of the photomultiplier voltage at $\pm 10 \mathrm{v}$.

\section{CONCLUSION}

To prevent ${ }^{14} \mathrm{C}$ ages from appearing too young, one must collect old samples from well-stratified sections free of roots and bacterial, fungal and algal activity. The reliability of age determination is noticeably increased by pretreatment procedures, such as wet sieving of sapropels and paleosols, to remove tiny roots, the division of peat and plant detritus into fine and coarse fractions, humus 
extraction by cold and hot $2 \% \mathrm{NaOH}$ and vigorous humic acid removal from old samples with repeated hot alkali treatment.

A large scintillation counter factor of merit is achieved by measuring ${ }^{14} \mathrm{C}$ activity in a small-volume liquid scintillator. A simple procedure developed in this laboratory for producing lithium carbide from charred organic samples facilitates scintillation counting. We can obtain large volumes of high-purity benzene, with a yield of up to $98 \%$, by using benzene synthesis on a $\mathrm{V}_{2} \mathrm{O}_{5} \cdot \mathrm{Al}_{2} \mathrm{O}_{3} \cdot \mathrm{SiO}_{2}$ catalyst. This procedure is now used in all ${ }^{14} \mathrm{C}$ laboratories in the former USSR as well as in some foreign laboratories. Our two homemade coincidence scintillation counters with powerful shield chambers provide large factors of merit and enable us to date old samples to $58,500 \mathrm{BP}$.

\section{REFERENCES}

Arslanov, Kh. A. 1967 Increasing the radiocarbon dating limit by means of scintillation technique to $60-65,000$ years. Bulletin of the Comission on Age Determination of Geological Formations 8: 154-163.

1971 On increasing radiocarbon dating reliability of Late Pleistocene sediments. In Radiocarbon. Vilnius Botanical Institute of the Lithuanian SSR Academy of Science: 205-214.

1975 Chemical preparation of fossil soils and other humus-containing samples for radiocarbon dating. In Experience and Methods of IsotopeGeochemical Research in the Baltic States and Belorussia. Riga: 48-49.

1987 Radiocarbon: Geochemistry and Geochronology. Leningrad University Press: $300 \mathrm{p}$.

Arslanov Kh. A., Butomo, S. V. and Kind, N. V. 1964 Sampling instructions for radiocarbon dating. In Absolute Geochronology of the Quaternary Period. Moscow, Academy of Science Press: 99-113.

Arslanov, Kh. A., Chernov, S. B. and Tertychnaya, T. V. 1987 Calibration of USSR radiocarbon standard by NBS standard and by pine rings for 1846-1855. In Methods of Isotope Geology. Moscow: 254-256.

Arslanov, Kh. A., Evzerov, V. Ja., Tertychny, N. I., Gerasimova, S. A. and Lokshin, N. V. 1981 On the age of Boreal transgression sediments on Kola peninsula. In Pleistocene Glaciation on the Eastern European Plains. Moscow: 28-37.

Arslanov Kh. A. and Filonov, B. A. 1978 On sample contamination by outside carbon during lithium carbide synthesis and ways of excluding it. In Astrophysical Phenomena and Radiocarbon. Tbilisi University Press: $349-352$.

Arslanov, Kh. A. and Gromova, L. I. 1968 Cyclical trimerization of acetylene and trialkylacetylenes on $\mathrm{CrO}_{3} \cdot \mathrm{Al}_{2} \mathrm{O}_{3} \cdot \mathrm{SiO}_{2}$ catalyst. Doklady Akademii Nauk SSSR 183(4): 881-884.

1969 Cyclical trimerization of acetylene and trialkylacetylenes on $\mathrm{NiMoO}_{4} \cdot \mathrm{Al}_{2} \mathrm{O}_{3}$ catalyst. Kinetika i Kataliz 10(4): 813-817.

Arslanov, Kh. A., Gromova, L. I., Polevaja, N. I. and Rudnev Ju. P. 1968 Radiocarbon age determination by the scintillation method. Geokhimiya 2: 198-206.
Arslanov, Kh. A. and Kozyreva, M. G. 1976 On the radiocarbon dating of recent soil profiles. In SeveroZapad Evropeiskoi Chasti SSSR 10: 99-112.

Arslanov, Kh. A. and Svezhentsev, Yu. S. 1993 An improved method for radiocarbon dating fossil bones. Radiocarbon, this issue.

Arslanov, Kh. A. and Tertychnaya, T. V. 1983 Some ${ }^{14} \mathrm{C}$ age change regularities of different fractions of organic samples. In Methods of Isotope Geology: Thesis of Reports from the Pan-USSR Seminar. Moscow: 141-143.

Arslanov, Kh. A. and Tertychny, N. I. 1970 On acetylene synthesis from $\mathrm{CO}_{2}$ for radiocarbon dating. In Astrophysical Phenomena and Radiocarbon. Tbilisi University: 55-60.

Arslanov, Kh. A., Tertychny, N.I., Lokshin, N. V., Gerasimova, S. A., Tertychnaya, L. V., Filonov, B. A. and Chernov, S. B. 1978a Study of ${ }^{14} \mathrm{C}$ concentration variations in surface sea waters by ${ }^{14} \mathrm{C}$ and ${ }^{230} \mathrm{Th} /{ }^{234} \mathrm{U}$ dating of marine mollusk shells. In Astrophysical Phenomena and Radiocarbon. Tbilisi University Press: 407-423.

Arslanov, Kh. A., Vergachov, V. A., Kocharov G. and Chernov S. B. 1978 b Variations of ${ }^{14} \mathrm{C}$ concentration in annual pine tree rings 1974-1984. In Astrophysical Phenomena and Radiocarbon. Tbilisi University Press: 27-36.

Chernov, S.B. and Arslanov, Kh. A. 1978 A precise single-channel setting stabilized by a light-diode for radiocarbon measurements. In Astrophysical Phenomena and Radiocarbon. Tbilisi University Press: 245252.

Chernov, S. B., Arslanov, Kh. A. and Ryvkin, A. S. 1978 Two-channel scintillation transistors setting for radiocarbon measurements. In Astrophysical Phenomena and Radiocarbon. Tbilisi University Press: 289300.

Noakes, J. E., Kim, S. M. and Stipp, J. J. 1965 Chemical and counting advances of liquid scintillation dating technique. In Proceedings of the 6th International Conference on Radiocarbon and Tritium Dating. Washington, DC, Clearinghouse for Federal Scientific and Technical Information, NBS: 68-98. 
Polach, H. A. and Stipp, J. J. 1967 Improved synthesis technique for methane and benzene radiocarbon dating. International Journal of Applied Radiation and Isotopes 18(6): 359-365.

Radnell, C. J. and Muller, A. B. 1980 Memory effects in the production of benzene for radiocarbon dating. In Stuiver, M. and Kra, R. S., eds., Proceedings of the 10th International ${ }^{14} \mathrm{C}$ Conference. Radiocarbon 22(2): 479-486.

Starik, I. E. and Arslanov, Kh. A. 1961 Radiocarbon age of some Quaternary samples. Doklady Akademii Nauk SSSR 13(1): 102-105.

Starik, I. E., Arslanov, Kh. A. and Klener, I. R. 1963 Improved chemical procedure of sample treatment for radiocarbon dating by means of scintillation technique. Radiokhimiya 5(2): 198-205.
Starik, I. E., Arslanov, Kh. A. and Zharkov, A. P. 1960 Scintillation technique of natural ${ }^{14} \mathrm{C}$ counting and its use for age determination. Radiokhimiya 2(2): 259260.

Starik, I. E., Shamov, V. A., Arslanov, Kh. A., Zharkov, A. P. and Murashov, G. M. 1961 Scintillation technique of natural ${ }^{14} \mathrm{C}$ counting and its use for age determination. Radiokhimiya 3(1): 101-113.

Tamers, M. A. 1969 Instituto Venezolano de Investigaciones Cientificas natural radiocarbon measurements IV. Radiocarbon 11(2): 396-422.

1975 Chemical yield optimisation of the benzene synthesis for radiocarbon dating. International Journal of Applied Radiation and Isotopes 26(11): 676-683. 